\title{
What motivates the most? Money or Empowerment: Mediating Role of Employee Commitment to Organizational Performance
}

\author{
Dr. Nadeem Akhtar ${ }^{1}$, Dr. Syed Muhammad Azeem², Dr. Abdullah F. Bassiouni ${ }^{3}$, \\ Dr. Teoh Kok Ban ${ }^{4}$, Adbulkhaliq Alvi ${ }^{5}$
}

1,2,3 Department of Management Sciences, Yanbu University College, Yanbu, Saudi Arabia

${ }^{4}$ School of Education and General Studies, SENTRAL College Penang, Malaysia

${ }^{5}$ Department of Management Sciences, Lahore Garrison Univesity, Pakistan

1- niazpur@gmail.com

2- azeemsyedmct@gmail.com

3- basiounia@rcyci.edu.sa

4- drderickteoh@gmail.com

5- khaliqalvi@gmail.com

\begin{abstract}
Aim - the study was an effort to understand the relationship between HRM practices and HR outcomes leading to organizational performance. For this purpose, the study tried to answer if the quality of the HR practices matters the most or quantity alone.

Design/Methodology - A structured questionnaire was used to collect data on HR practices, employee commitment, and organizational performance. Data was collected from the 759 employees of the industrial sector in Saudi Arabia.

Findings - The study reveals that empowerment is a strong predictor of organizational performance than compensation. Moreover, employee commitment (mediate) partially contributes to organizational performance.

Practical Implications - HR practitioners may collect the employees' data more regularly to learn if HR practices produce the desired commitment level to produce organizational performance.

Originality/Value - In doing so, it shed some light on how HR practitioners should implement and improve HR practices.
\end{abstract}

Keywords: Empowerment, Commitment, Perceived organization performance 


\section{Introduction}

One of the all-time challenges for organizations has been how to get the best of their employee's abilities (Gunlu, Aksarayli, \& Perçin, 2010). For this, researchers of organizational behavior have been investigating HR practices, contributing the most to organizational performance since the $19^{\text {th }}$ century. The HR practices are designed to motivate the employee, which further leads to organizational performance ( $\underline{R}$. A. Parker, 2008). Numerous research studies have tried to unlock motivation factors. Herzberg's two-factor theory is considered the most researched and comprehensive (Sobaih \& Hasanein, 2020). Herzberg two factor theory was presented eight decades ago. It proposed two sets of factors - motivation and hygiene factors. Those motives still drive us to design the best HR practices.

The HRM practices that contribute to employee commitment in one organization and management style may not be valid in another country's organization with a different decision-making style (Hyun \& Oh, 2011). The research studies infer that HRM practices lead to firms' financial and non-financial performance (Katou \& Budhwar, 2006). A broad group of writing exists investigating the effect of these HR practices (compensation and empowerment) on HR outcomes (organizational commitment) and examining any interceding role of these HR outcomes on organizational performance in developed nations. For instance, Huselid (1995) approved that compensation practices primarily influence employee commitment. Taormina (1999) found a critical effect of compensation practices on employee retention. Likewise, empowerment is another HR management strategy that gives the employee the necessary authority to decide while carrying out the assigned task. This paper investigates which of the two HR practices - compensation and empowerment - contributes the most towards the organizational performance, until the late $20^{\text {th }}$-century Saudi labor laws governing human resource management were dated back to 1969 (Mellahi \& Wood, 2002). Most of the HR managers were not trained in skills in their field. This resulted in the outdated practices of managing the people (Bhuian, Al-shammari, \& Jefri, 2001). Now the Saudi Government has introduced the legal framework for all the organizations on how to manage people (Mellahi, 2007). This appropriate interference in HRM practices and procedures will generate an extensive body of research. However, the author could not find any study in the Saudi context, which measures the effect of compensation or empowerment on the best predictor of organization performance. So, the study will fill this gap. The investigation results will enormously assist managers with emphasizing appropriate HR practice as per their importance to persuade and fulfill their employees prompting increased organizational performance (OP).

\section{Literature Review and Hypothesis Development}

The discussion concerning the connection between HRM practices and OP can be classified into direct and indirect relationships (Chand \& Katou, 2007). The subsequent methodology suggests an indirect effect of individual HRM practices and, additionally, the heap of HRM outcomes (employee commitment) on organizational performance, as indicated by Wright et al. (Wright, Gardner, \& Moynihan, 2003). Among all HRM practices discussed above, we selected empowerment and compensation practices as candidates to test their direct and indirect impacts on organizational performance as initially proposed by Herzberg (1959) and Hackman and Oldham (1980) and widely tested in subsequent research (Mehrjouyan, 2019; Ramirez-Garcia, Perea, \& Junco, 2019; Teems \& Helbing, 2017; Tholath \& Thattil, 2016; Wang, Liu, \& $\mathrm{Zhu}, 2018)$. These two practices show the fundamental difference between managers' and employees thinking. So, this study is an effort to explore and find if it was right in the $20^{\text {th }}$ century is still valid in the $21^{\text {st }}$ century

Organizational performance is a primary predictor of corporate progress. The organizational performance is perhaps the most significant predictor and widely researched dependent variable in organizational in 
management sciences studies(Alatailat, Elrehail, \& Emeagwali Okechukwu, 2019). As per Richard, Devinney, Yip, and Johnson (2009), Organization performance is an indicator that decides how well an organization accomplishes its stated goals. The organizations' performance can be assessed based on the bottom line or in a non-traditionally - non-financial - way (Shin, Sung, Choi, \& Kim, 2015). Non-financial indicators need to be evaluated to determine overall efficiency for two essential purposes (Ndregjoni \& Elmazi, 2012). First, the company includes many social groups that have different priorities and objectives relevant to the organization. Second, the required fields of the industry do not generally have to have financial implications. Thus, there are several non-financial predictor strategies, such as consumer loyalty and retaining the customer, competitiveness and performance, credibility, and brand image. Ostroff and Bowen (2016) have heightened the poorly defined term of organization performance in the literature. Yet, there are a researchers like Meier and O'Toole (2012) and Gomez-Mejia, Berrone, and Franco-Santos (2014) has used the subjective measures such as employee satisfaction, employee commitment and other behavioral aspects to evaluation the organization performance. For this study, we focus on measuring the non-financial performance of the organization. For this, we use the perception of the employees to measure organizational performance.

\subsection{Employee Empowerment (EE) and Organizational Performance (OP)}

It is a simple belief that an individual believes that he is in control of his task (Hartline \& Ferrell, 1996). Zimmerman (2000) theory of empowerment suggests that it is a process by which individuals learn to exert control. Inspiring employees to take psychological responsibility can view how empowerment may present a significant element in its operation (Thomas \& Velthouse, 1990). It involves factors that boost intrinsic motivation without limiting the fundamental principles of self-efficacy and commitment. Empowerment underlines that confidence is a more specific motivating mechanism that enhances the drive for an internal job and emphasizes the significance of individual identity and understanding of its position. According to Katou (2008) and Ioannidou, Karagiorgos, and Alexandris (2016), the essence of employees' empowerment is to recognize psychological variables that may influence organizational performance directly or indirectly. In organizational settings, the empowerment process increases individual participation and increases organizational effectiveness. In this context, the study assumes that organizations that empower their employees can better achieve their goals. So, we posit the following hypothesis:

H1 - Employee Empowerment has a positive impact on the organizational performance

\subsection{Employee Empowerment and Organizational Commitment (OC)}

EE prompts significant social results (Chow, Lo, Sha, \& Hong, 2006). For example, EE gives selfconfidence and discretionary power to the employee to make decisions related to the assigned task (Conger \& Kanungo, 1988). In another study conducted by Ruiz-Palomo, León-Gómez, and García-Lopera (2020), it is suggested that EE considerably increases the OC of the employees. EE is becoming a top concern for the industry managers as it is proven that employees with high empowerment levels are more committed and loyal to their organizations. OC is defined by Dunham, Grube, and Castaneda (1994) as a measure when individual matches personal values with organizational goals. Therefore, we propose the following research hypothesis:

H2 - Empowerment has a positive impact on the Organizational Commitment level 


\subsection{Compensation and Organizational Performance}

Various analysts express that engaging worker with significant support levels from the top administrative level helps the worker attain self-fulfillment, which then hugely impacts the organization's performance (Chhabra, 2016). Compensation as a method of controlling human capital and promoting understanding has many significances. Originally, compensation was used to refer to the process and practice that requires companies to compensate workers proportionately, depending on their degree of achievement and role (Gyensare \& Asare, 2012; Hewitt, 2009; Zhou, Vohs, \& Baumeister, 2009). Therefore, compensation is not a free offer but a salary or a benefit earned through work that can affect operational performance in nearly every operational functioning area. The creation and execution of effective compensation systems will not only impact productivity. Still, they can also be used to increase health, efficiency, ingenuity, competitiveness, commitment, and a host of other vital outcomes in a competitive workforce (Dessler, 2006; Muhammad \& Abdullah, 2016).

H3 - Compensation has a positive impact on organizational performance

\subsection{Compensation and Organizational Commitment}

Compensations are awarded to the employees in exchange for their services to the organization. This equitable reward management system enhances the organization's commitment level (Aladwan, Bhanugopan, \& D'Netto, 2015). In a study by O. Parker and Wright (2001), it is observed that reward and compensation perception can lead the employee to leave the organization. This outcome shows a lower level of commitment as a result of inadequate compensation. The argument is that if the organizations want to enhance their employees' commitment level, they must implement an equitable and fair compensation system. Other studies, like Teclemichael Tessema and Soeters (2006) and Uraon (2018), have found a strong connection between the two variables. Recent research by Aboramadan, Albashiti, Alharazin, and Dahleez (2020) in the academic setting established that employees with the perception of a fair reward system were obliged to work harder to pay back to the organization. So for the research, we hypothesized:

\section{H4 - Compensation increases the employee Commitment level}

\subsection{Organizational Commitment-Mediator}

Organizational commitment can be viewed as the attitude of a person towards his/her organization consisting of deep faith in and recognition of the organization's aims and values, eagerness to make substantive efforts for the organization (Muhammad \& Abdullah, 2016). According to Allen and Meyer (1990), commitment also applies to workers' dedication to connecting with and helping the company. Employees with commitment stay with the company as they can do so, not so much as a consequence of any coercion or obligation imposed onto them by an outsider. Accordingly, continuing commitment applies to paying attention to the costs involved with quitting the company. Researchers suggested that commitment can be mediating the relationship between both empowerment and compensation from one side and organizational performance on the other side (Dessler, 2006; Ioannidou et al., 2016; Katou, 2008; Muhammad \& Abdullah, 2016).

H5 - OC has a positive impact on the organizational performance

H6-OC mediates the correlation between empowerment and organizational performance

$H 7-O C$ mediates the correlation between compensation and organizational performance 


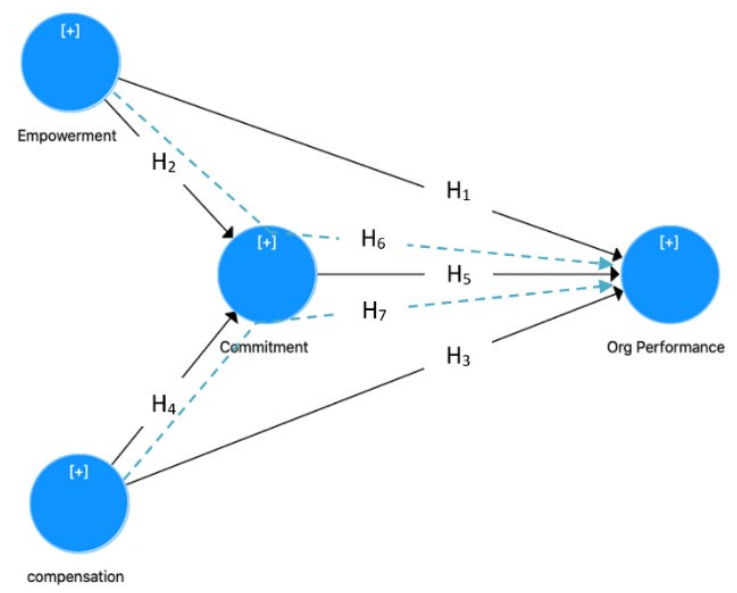

Figure 1 - Conceptual Framework

Source: Adapted from Bae and Lawler (2000), (Som, 2008), Teclemichael Tessema and Soeters (2006)

\section{Methodology}

This study aims to investigate the impact of HR practices on Perceived Organizational performance in Saudi Arabia. For the reason stated, the data has been collected from the university teachers of various public and private sector universities of Saudi Arabia.

The questionnaire was administered to measures HR Practices, namely Compensation and Empowerment, which includes nine items: Compensation with four items and empowerment with five items. Scale measurement of compensation was adapted from (Teclemichael Tessema \& Soeters, 2006). Four items were used to measure compensation. The compensation scale questions asked questions about the attractiveness and if the compensation system is equitable internally/externally. Likewise, the scale of empowerment had a total of 5 items. It was adapted from (Wan, Ong, \& Kok, 2002). The sample item was asked if "your organization permitting enough discretion in doing work."

Five items were adapted from Modway, Porter, Steers, and Porter (1982) organization commitment scale. A sample item is, "I am willing to put in a great deal of effort beyond that normally expected to help this organization be successful." Similarly, Organizational performance was measured on seven items adapted from (Delaney \& Huselid, 1996). Respondents were asked about the quality of products, development of new services, and satisfaction of customers.

Three reminders were sent with an interval of one week, giving us 759 responses. The data was collected on google form, which was shared with the HR representative of the company to circulate further among the company employees. All the questions were marked mandatory, so there were no missing or incomplete questionnaires. The responses are then analyzed by using Smart PLS-SEM. Initially, Cronbach Alpha and Rho-A values were ascertained to assesses the reliability of the scale (see figure 2). Measurement model assessment was carried out for the reflective and formative constructs by calculating the composite reliability (CR) and average variance extract (AVE). Item loading and discriminant validity were also calculated to ensure reliability. The structural model assessment was carried out by calculating the path coefficient (hypotheses) among the variables under study so that decisions can be made to accept or reject the hypotheses, assess R square, effect size $\mathrm{f}^{2}$, and predictive relevance of the whole model. 


\section{The result, Discussion, and Hypothesis Testing}

Composite reliability was established to ensure internal consistency reliability (see Table 1 and Table 2). The outer loading value of all the items is found to be more than 0.70 . This establishes the reliability of the latent variables used in the model. Obtained AVE values with consistent composite reliability values confirm the attainment of convergent validity.

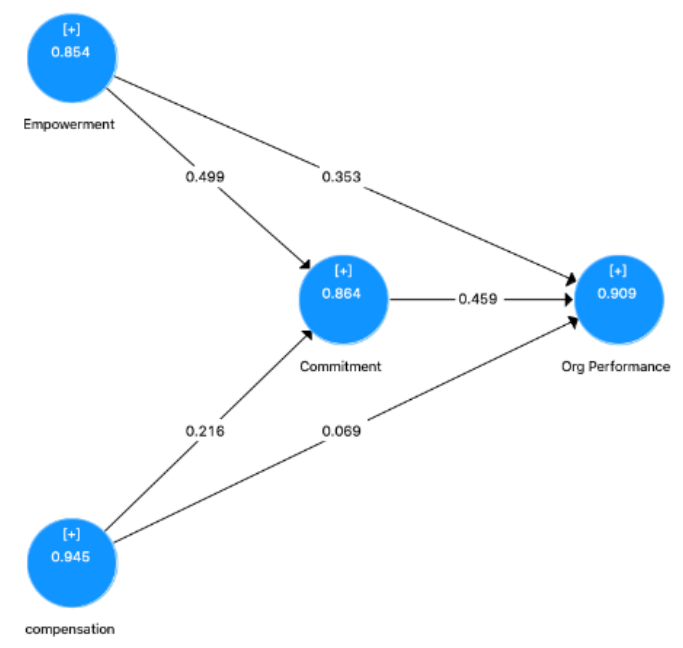

Figure 2 - Path Coefficent and Rho_A values

Table 1 - Measurement Model (Convergent Validity and Construct Reliability)

\begin{tabular}{llrrrr} 
& Items & Loadings & Rho_A & CR & AVE \\
\hline Organization & orgp1 & 0.790 & 0.909 & 0.926 & 0.640 \\
Performance & orgp2 & 0.767 & & & \\
& orgp3 & 0.793 & & & \\
& orgp4 & 0.834 & & & \\
& orgp5 & 0.846 & & & \\
& orgp6 & 0.851 & & 0.958 \\
& orgp7 & 0.712 & & & \\
\hline Compensation & comp1 & 0.903 & 0.945 & & \\
& comp2 & 0.931 & & & \\
& comp3 & 0.915 & & & \\
& comp4 & 0.943 & & & \\
\hline Empowerment & empo1 & 0.880 & 0.854 & & \\
& empo2 & 0.879 & & & \\
& empo3 & 0.869 & & & \\
\hline Commitment & commit3 & 0.897 & 0.864 & & \\
& commit4 & 0.861 & & & \\
& commit5 & 0.884 & & & \\
\hline
\end{tabular}

Items removed: indicator items are below Cronbach Alpha 0.7: Commit1, commit2

a) All items loading $>0.5$ indicates indicator reliability (Hulland, 1999)

b) All average variance Extracted (AVE) $>0.5$ as indicates convergent reliability (Bagozzi, Yi, \& Nassen, 1998; Fornell \& Larcker, 1981)

c) All composite reliability (CR) $>0.7$ indicates internal consistency (Gefen, Straub, \& Boudreau, 2000)

d) All Cronbach's alpha $>0.7$ indicates indicator reliability (Nunnally, 1978) 
Table 2 presents the result of discriminant validity evaluation. The Diagonal is the square root of the AVE of the latent variables and indicators the highest in any column or row.

Table 2 - Discriminant Validity (Fornell and Larcker Criterion)

\begin{tabular}{lrrrr} 
& Commitment & Empowerment & Org Performance & Compensation \\
\hline Commitment & 0.881 & & & \\
Empowerment & 0.669 & 0.876 & & \\
Org Performance & 0.737 & 0.714 & 0.800 & 0.923 \\
\hline Compensation & 0.608 & 0.785 & 0.625 & 0.96 \\
\hline
\end{tabular}

Table 3 - Discriminant Validity (HTMT)

Commitment

Empowerment Org Performance Compensation

\begin{tabular}{llll}
\hline Commitment & & & \\
Empowerment & 0.775 & & \\
Org Performance & 0.826 & 0.807 & \\
Compensation & 0.674 & 0.878 & 0.669 \\
\hline
\end{tabular}

In the first place, we found that measures of two variables, i.e., compensation and empowerment, were correlated. So the researchers eliminated the highly correlated item on opposing construct- empowerment (empow4) and (empow5). Removal of these indicators from the opposing constructs established the discriminant validity at HTMT0.90 (see table 3). Therefore, discriminant validity is established. The same finding holds for the HTMT inference criterion, which has been established by running the bootstrapping routine. Thus, in conclusion, we have found that discriminant validity has been established for the model (Figure 3). The variance inflation factor (VIF) was computed to assess the collinearity, and all the constructs were below five, which shows there was no multicollinearity among the variables.

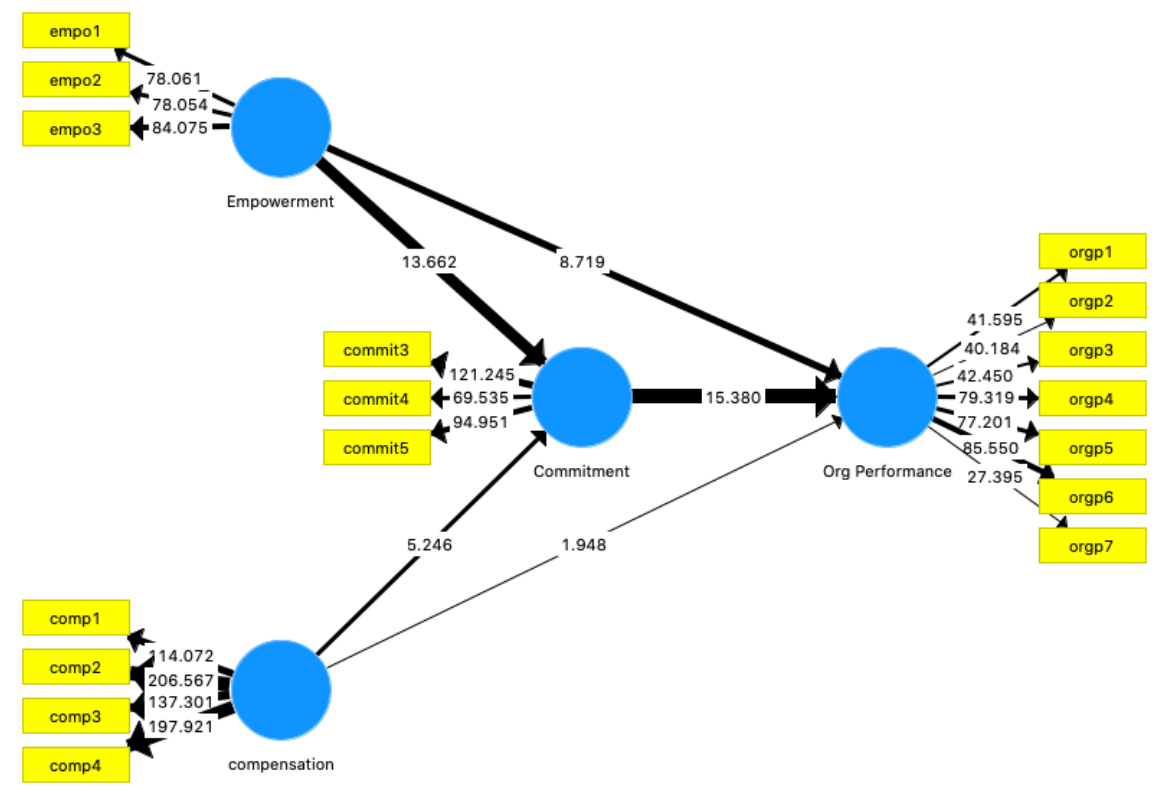

Figure 3 - Hypothesis Testing: Bootstrapping direct effect results 
Table 4 - Structural model Hypothesis Testing: Bootstrapping Direct Effect Result

\begin{tabular}{llcccccccc}
\hline & Relationship & $\begin{array}{c}\text { Std } \\
\text { Beta }\end{array}$ & $\begin{array}{c}\text { Std } \\
\text { Error }\end{array}$ & $\begin{array}{c}\mid \mathbf{t} \text { - } \\
\text { value }^{\wedge}\end{array}$ & Decision & $\mathbf{f}^{2}$ & $\begin{array}{c}\text { Effect } \\
\text { Size }\end{array}$ & $\begin{array}{c}\mathbf{9 5 \% C I} \\
\text { LL }\end{array}$ & $\begin{array}{c}\text { 95\%CI } \\
\text { UL }\end{array}$ \\
\hline H1 & $\begin{array}{l}\text { Empowerment }> \\
\text { Org Performance }\end{array}$ & 0.354 & 0.041 & $8.719^{* *}$ & accepted & 0.111 & Weak & 0.287 & 0.421 \\
\hline H2 & $\begin{array}{l}\text { Empowerment }> \\
\text { Commitment }\end{array}$ & 0.500 & 0.037 & $13.662^{* *}$ & accepted & 0.179 & Moderate & 0.439 & 0.560 \\
\hline H3 & $\begin{array}{l}\text { Compensation }> \\
\text { Org Performance }\end{array}$ & 0.068 & 0.035 & $1.948^{* *}$ & Rejected & 0.005 & Weak & 0.010 & 0.127 \\
\hline H4 & $\begin{array}{l}\text { Compensation }> \\
\text { Commitment }\end{array}$ & 0.215 & 0.041 & $5.246^{* *}$ & accepted & 0.033 & Weak & 0.147 & 0.283 \\
\hline H5 & $\begin{array}{l}\text { Commitment }> \\
\text { Org Performance }\end{array}$ & 0.459 & 0.030 & $15.380^{* *}$ & accepted & 0.308 & Moderate & 0.410 & 0.508 \\
\hline
\end{tabular}

- $\quad * * \mathrm{p}<0.01, * \mathrm{p}<0.05$

- $\quad \mathrm{R}^{2}$ (Organization Performance $=0.634$, Adjusted $\mathrm{R}^{2}=0.632 ; \mathrm{R}^{2}($ Commitment $=0.465$, Adjusted $\left.\mathrm{R}^{2}=0.463\right)$

- Effect Size impact indicator are according to Cohen (1998), $\mathrm{f}^{2}$ values: 0.35(strong), 0.15(moderate), and 0.02(weak)

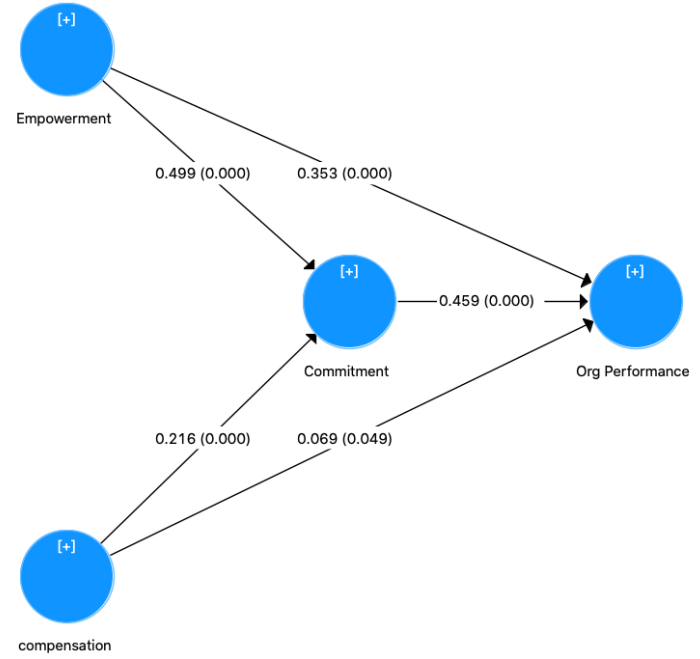

Figure 5 - Path Coefficient and P-Values

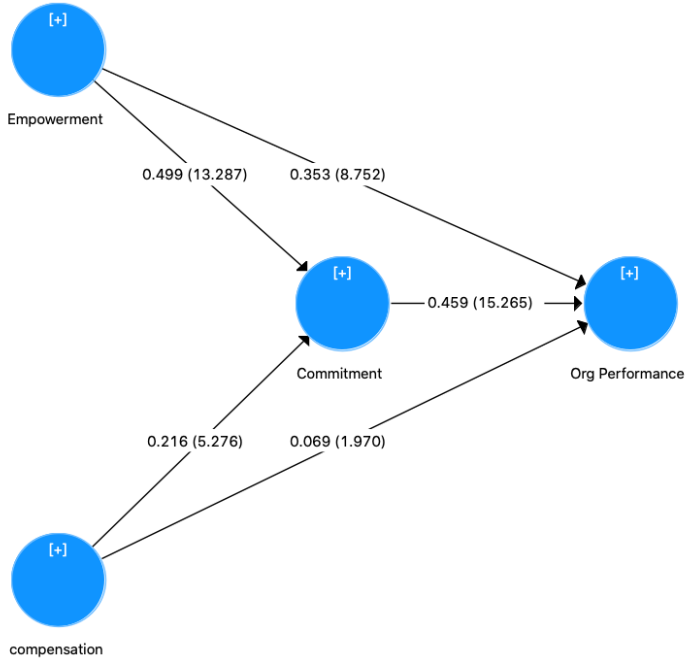

Figure 4 - Path Coefficient and T-Values

Table 4, Figure 4, and Figure 5 represent the direct relationship between the variables used and their effect size. The $\mathrm{R}^{2}$ is a measure of the model's predictive accuracy. It represents the variance in the endogenous constructs explained by all of the exogenous constructs linked to it.

The effect size was assessed to see how strongly one exogenous construct contributes to explaining a particular endogenous construct in $\mathrm{R}^{2}$.

Rule of thumb $\mathrm{f}^{2}$ (Cohen 1988)

$0.02<=\mathrm{f}^{2}<0.15$ : weak effect

$0.15<=\mathrm{f}^{2}<0.35$ : moderate effect

$\mathrm{f}^{2}=>0.35$ : strong effect 


\section{Model fitness}

SRMR value is 0.072 which is less than 1 . It shows the fitness of the model (Henseler, Ringle, \& Sarstedt, 2015).

The $\mathrm{R}^{2}$ value was obtained for each latent variable to assess the structural model (Figure 4 and Figure 5). Secondly, the bootstrap function was used to determine whether the structural model's path coefficients are significant or not and if their effect size is sufficiently big enough. A one-tailed test was used because of the predetermined direction of the relationship between all hypothesized variables of the theoretical framework. A 5000 bootstrap sample was used for this study, constituting the same number of observations as that of the original sample to generate the standard errors and t-values (Joseph F Hair, Ringle, \& Sarstedt, 2013).

Besides, the interaction effect was checked through $\mathrm{f}^{2}$ values representing effect size. The coefficient of the determinant "R-square" value represents how much variance in a target variable is explained by the effect size of the independent variables linked to it (Joe F Hair, Ringle, \& Sarstedt, 2011). Cohen (2013) recommended benchmark values for R-square as 0.75 (substantial), 0.50 (moderately strong) and 0.25 (weak)

Table 4 revealed that all the direct relationships are significant. $\mathrm{H} 3$ is rejected due to very low value of $\beta$ and $\mathrm{F}^{2}$. Also, empowerment $\beta=0.5$ and compensation $\beta=-0.21$ explained $46.5 \%$ variance in commitment. Empowerment $\beta=0.354$ and compensation $\beta=-0.068$ explained $63.4 \%$ variance in organizational performance.

Moreover, empowerment and compensation had a significant positive effect on commitment $(\mathrm{t}=13.662, \mathrm{p}$ $=.01$ and $\mathrm{t}=5.246, \mathrm{p}=.01)$. Empowerment and compensation had a significant positive effect on organizational performance $(t=8.719, \mathrm{p}=.01$ and $\mathrm{t}=1.948)$.

All direct relationships proved significant, with t-values well above a threshold of 1.96 and p-values of 0.01. Similarly, based on the $t$-value rule of thumb for interpretation of a two-tailed test, i.e., $t=1.96$, all the hypotheses were supported with one exception, namely H3. Table 4 also indicates the values for $\mathrm{f}^{2}$, which explain the relationship path between the independent and response variables. Commitment to organizational performance $\left(\mathrm{f}^{2}=0.308\right)$ indicates the moderate effect size. Empowerment and compensation to organizational performance $\left(\mathrm{f}^{2}=0.111\right.$ and $\left.\mathrm{f} 2=0.005\right)$ indicate weak effect size. Empowerment to commitment $\left(\mathrm{f}^{2}=0.179\right)$ indicates moderate effect size.

Compensation is found to have shallow interaction with organizational performance $\left(\mathrm{f}^{2}=0.005\right)$ and commitment $\left(\mathrm{f}^{2}=0.033\right)$ due to the $\mathrm{f}^{2}$ values being below the minimum threshold. The $\mathrm{R}$-square values are also displaying a convincing explanation of variance by the chosen independent variables.

\section{Mediating effect}

A mediating effect is created when a third variable/construct intervenes between two other related constructs. A mediator specifies how (or the mechanism by which) a given effect occurs (Baron \& Kenny, 1986; James \& Brett, 1984).

Individual indirect effects and the corresponding standard deviation from the bootstrapping of 5000 samples are obtained for the t-statistics calculation about the indirect impact following the recommendations of Hayes and Preacher (2014). 
Table 5 - Indirect Relationships for Hypothesis testing

\begin{tabular}{llllllll}
\hline H6 & Empowerment $->$ Commitment $->$ Org Performance & 0.229 & 0.023 & $10.133^{* *}$ & accepted & 0.195 & 0.27 \\
\hline H7 & Compensation $>$ Commitment $>$ Org Performance & 0.099 & 0.019 & $5.164^{* *}$ & accepted & 0.068 & 0.13 \\
\hline
\end{tabular}
$* * \mathrm{p}<0.01, * \mathrm{p}<0.05$

Table 5 presents the mediation of the hypothesized relationship of commitment to empowerment and organizational performance (H6). The mediation effect of commitment is supported with $\beta$ value $=0.229$ and a t-value of 10.133. Similarly, the mediation of the hypothesized relationship of responsibility on compensation and organizational performance is also supported with $\beta$ value $=0.099$ and a t-value of 5.164 .

\begin{tabular}{|c|c|c|c|c|c|c|c|c|}
\hline \multirow[t]{2}{*}{ Hypothesis } & \multirow{2}{*}{\begin{tabular}{|c|}
\multicolumn{1}{|c|}{} \\
$\begin{array}{l}\text { Path } \\
\text { coeff }\end{array}$ \\
\end{tabular}} & \multirow{2}{*}{\begin{tabular}{|l} 
b \\
\\
$\begin{array}{l}\text { Path } \\
\text { coeff }\end{array}$ \\
\end{tabular}} & \multicolumn{2}{|c|}{$a * b$} & \multirow{2}{*}{\begin{tabular}{|c|} 
Total Effect \\
(c) \\
Path coeff
\end{tabular}} & \multicolumn{2}{|c|}{$\begin{array}{l}\text { Percentile } 95 \% \\
\text { confidence } \\
\text { intervals }\end{array}$} & \multirow{2}{*}{$\begin{array}{l}\text { Method } \\
\text { VAF a }\end{array}$} \\
\hline & & & Path coeff & t-value & & $\begin{array}{c}95 \% \\
\text { LL } \\
\end{array}$ & $\begin{array}{c}95 \% \\
\text { UL } \\
\end{array}$ & \\
\hline $\begin{array}{l}\text { Empowerment }> \\
\text { Commitment }>\text { Org } \\
\text { Performance }\end{array}$ & 0.499 & 0.459 & 0.229041 & $10.133 * *$ & 0.582041 & 0.195 & 0.27 & 0.39351352 \\
\hline $\begin{array}{l}\text { compensation }> \\
\text { Commitment }>\text { Org } \\
\text { Performance }\end{array}$ & 0.216 & 0.459 & 0.099144 & $5.164 * *$ & 0.168144 & 0.068 & 0.13 & 0.58963745 \\
\hline
\end{tabular}

Table 6 shows, the indirect effect of empowerment on organizational performance is positive and significant $(\mathrm{IE}=0.229$ and $\mathrm{t}$-value $=10.133)$ at $\mathrm{p}<0.01$, as well as interval confidence, which was different from zero $(0.195,0.27)$. Also, the indirect effect of compensation on organizational performance is positive and significant $(\mathrm{IE}=0.0991$ and $\mathrm{t}$-value $=5.164)$ at $\mathrm{p}<0.001$, as well as interval confidence, which was different from zero $(0.068,0.13)$. At this point, the significance of the indirect effect is established. To examine the strength of the mediator variable on the dependent variable, VAF is to be calculated. VAF is a ratio of the indirect-to-total effect (Nitzl \& Hirsch, 2016). VAF stands for the variance accounted for value. The value of VAF determines the degree to which the mediation contributes the variance of the dependent variable. The simple formula for calculating the VAF is the VAF=indirect effect/total effect. The value of VAF in $\mathrm{H} 6$ is 0.394 , and in $\mathrm{H} 7$ is 0.589 .

The following conditions are suggested by Joseph F Hair et al. (2013) to explain the mediation: If $0<$ VAF $<0.20$, then No Mediation. ii) If $0.20<\mathrm{VAF}<0.80$, then Partial Mediation. iii) If VAF $>0.80$, then Full Mediation. It can be stated that only $39.4 \%$ of empowerment effect on organizational performance can be explained by commitment as a mediator. Since the value is greater than 0.20 , the magnitude is considered to be partial.

On the other hand, $58.96 \%$ of the compensation effect on organizational performance can be explained by commitment as a mediator. The magnitude is also partial. These findings lead to the acceptance of H6 and H7 about commitment's mediator role.

\section{Hypothesis Testing}

This study was designed to examine the influence of social resource practices (empowerment and compensation) on organizational performance with a mediating effect of commitment between the two. 


\section{Hypothesis 1: Employee Empowerment has a positive impact on organizational performance.}

Table 4 reveals that employee empowerment is significantly related to organizational performance with a

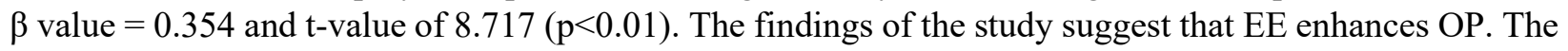
study's finding is consistent with some prior studies (Ioannidou et al., 2016; Katou, 2008). The results of previous studies have provided strong evidence that the employees who are allowed to control their efforts at work demonstrate high internal motivation that eventually leads to higher individual and organizational performance.

\section{Hypothesis 2: Empowerment has a positive impact on the Organizational Commitment level.}

Table 4 demonstrated a significant relationship between $\mathrm{EE}$ and $\mathrm{OC}$ with a $\beta$ value $=0.500$ and a $\mathrm{t}$-value of $13.662(\mathrm{p}<0.01)$. The result is supported by previous studies (Chow et al., 2006; Ruiz-Palomo et al., 2020). The more empowered the employees are, the better their level of commitment is seen. When employees are given responsibilities and decision-making opportunities, they become more sincere and committed to their assigned work and the organization.

\section{Hypothesis 3: Compensation has a positive impact on organizational performance.}

Table 4 shows the weak relationship between compensation and organizational performance with a $\beta$ value $=0.068$ and a $\mathrm{t}$-value of $1.948(\mathrm{p}<0.01)$. The study's result is consistent with previous findings (Chhabra, 2016; Gyensare \& Asare, 2012). Since the values are not satisfying the criteria conditions, the hypothesis is rejected statistically.

\section{Hypothesis 4: Compensation increases the employee Commitment level.}

The compensation is significantly related to a commitment with a $\beta$ value $=0.215$ and a t-value of 5.246 $(p<0.01)$. The result establishes support for the findings of the previous findings (Aboramadan et al., 2020; O. Parker \& Wright, 2001; Uraon, 2018). The appropriate compensation given to employees for their services improves their commitment and loyalty to the organization. Well-estimated compensation wiped out all kinds of inaccurate perceptions and frustrations among the employees.

Hypothesis 5: Organizational commitment has a positive relationship with organizational performance.

It is quite apparent from table 4 that $\mathrm{OC}$ is significantly related to the $\mathrm{OP}$ with a $\beta$ value $=0.459$ and a tvalue of $15.38(\mathrm{p}<0.01)$. The effect size between the two is found the highest as well. The result is in line with the previous research findings of Dessler (2006). The consistency in workers 'commitment increases the company's sustainability and performance in the long run. The HR practices need to be adopted and implemented carefully so that employees' commitment continues toward their role in particular and organization in general.

Hypothesis 6: Organizational commitment mediates the correlation between empowerment and organizational performance.

Table 5 presents the mediation of OC's hypothesized relationship on employee empowerment (EE), and OP is also supported with $\beta$ value $=0.299$ and a t-value of 10.13. This study's result is consistent with the study of Karavardar (2014), which shows that EE is associated with OP through OC as a mediating variable. The result highlights that $\mathrm{EE}$ as a valuable internal resource may improve OP through OC. Also, if an organization focuses on employee empowerment in achieving workers' personal and organizational goals, it can develop commitment among the workers, which eventually improves the OP. Therefore, organizations must provide employees with decision-making opportunities to develop a commitment to enhancing organizational performance. 


\section{Hypothesis 7: Organizational commitment mediates the correlation between compensation and organizational performance.}

Table 5 presents the mediation of OC's hypothesized relationship on compensation, and OP is also supported with $\beta$ value $=0.099$ and a t-value of 5.164. This study's result is consistent with some of the studies of Ibrahim, Abdullah, and Kaliappen (2016), which show that compensation is associated with OP through $\mathrm{OC}$ as a mediating variable. The result highlights that compensation as a valuable internal resource may improve OP through OC. Also, if organizations are fair and reasonable in their compensation calculation for employees' input in achieving organizational goals, they can develop commitment among the workers, which eventually improves the OP. Therefore, the organizations need to offer employees the best reasonable rewards for their contribution to achieving the set goals.

The overall results revealed that $\mathrm{H} 1, \mathrm{H} 2, \mathrm{H} 4$, and $\mathrm{H} 5$, are significantly supported and demonstrated in table 4. $\mathrm{H} 3$ is rejected as its effect size is found to be weak. H6 and $\mathrm{H} 7$ are significantly proved and supported by previous findings.

\section{Conclusion}

This study was conducted to understand the mediation effect of commitment on the relationship between empowerment and organizational performance. Similarly, to understand the mediation effect of commitment on the relationship between compensation and organizational performance. The findings established that commitment is capable of mediating the relationship between empowerment and organizational performance and between compensation and organizational performance. The study contributes to the existing knowledge by examining the relationships empirically and statistically. Many studies have suggested that sound and effective HR practices play a significant role in leading and achieving organizational performance. The study was carried out in the Saudi Arabian context, where HR practices are professionally adopted by most medium and large organizations. This leads to the sustainability of these organizations and eventually making HR more stable and efficient in retaining human resources. The study recommends using a large sample, including other sector organizations, adding other HR practices to establish their effectiveness in organizational success. The model needs to be expanded and can be validated by future research.

\section{References}

Aboramadan, M., Albashiti, B., Alharazin, H., \& Dahleez, K. A. (2020). Human resources management practices and organizational commitment in higher education. International Journal of Educational Management.

Aladwan, K., Bhanugopan, R., \& D'Netto, B. (2015). The effects of human resource management practices on employees' organisational commitment. International Journal of Organizational Analysis.

Alatailat, M., Elrehail, H., \& Emeagwali Okechukwu, L. (2019). High performance work practices, organizational performance and strategic thinking: A moderation perspective. International Journal of Organizational Analysis, 27(3), 370-395. doi: 10.1108/IJOA-10-2017-1260

Allen, N. J., \& Meyer, J. P. (1990). The measurement and antecedents of affective, continuance and normative commitment to the organization. Journal of Occupational Psychology, 63(1), 1-18. doi: $10.1111 / \mathrm{j} .2044-8325.1990 . t b 00506 . x$

Bae, J., \& Lawler, J. J. (2000). Organizational and HRM strategies in Korea: Impact on firm performance in an emerging economy. Academy of Management journal, 43(3), 502-517. 
Bagozzi, R. P., Yi, Y., \& Nassen, K. D. (1998). Representation of measurement error in marketing variables: Review of approaches and extension to three-facet designs. Journal of Econometrics, 89(1-2), 393-421.

Baron, R. M., \& Kenny, D. A. (1986). The moderator-mediator variable distinction in social psychological research: Conceptual, strategic, and statistical considerations. Journal of personality social psychology, 51(6), 1173.

Bhuian, S. N., Al-shammari, E. S., \& Jefri, O. A. (2001). Work-related attitudes and job characteristics of expatriates in Saudi Arabia. Thunderbird International Business Review, 43(1), 21-32.

Chand, M., \& Katou, A. A. (2007). The impact of HRM practices on organisational performance in the Indian hotel industry. Employee Relations, 29(6), 576-594.

Chhabra, B. (2016). Work role stressors and employee outcomes. International Journal of Organizational Analysis.

Chow, I. H.-s., Lo, T. W.-c., Sha, Z., \& Hong, J. (2006). The impact of developmental experience, empowerment, and organizational support on catering service staff performance. International Journal of Hospitality Management, 25(3), 478-495.

Cohen, J. (2013). Statistical power analysis for the behavioral sciences: Academic press.

Conger, J. A., \& Kanungo, R. N. (1988). The empowerment process: Integrating theory and practice. Academy of Management Review, 13(3), 471-482.

Delaney, J. T., \& Huselid, M. A. (1996). The impact of human resource management practices on perceptions of organizational performance. Academy of Management journal, 39(4), 949-969.

Dessler, G. (2006). A framework for human resource management: Pearson Education India.

Dunham, R. B., Grube, J. A., \& Castaneda, M. B. (1994). Organizational commitment: The utility of an integrative definition. Journal of Applied psychology, 79(3), 370.

Fornell, C., \& Larcker, D. F. (1981). Structural equation models with unobservable variables and measurement error: Algebra and statistics: SAGE Publications Sage CA: Los Angeles, CA.

Gefen, D., Straub, D., \& Boudreau, M.-C. (2000). Structural equation modeling and regression: Guidelines for research practice. Communications of the association for information systems, 4(1), 7.

Gomez-Mejia, L. R., Berrone, P., \& Franco-Santos, M. (2014). Compensation and organizational performance: Theory, research, and practice: Routledge.

Gunlu, E., Aksarayli, M., \& Perçin, N. Ş. (2010). Job satisfaction and organizational commitment of hotel managers in Turkey. International Journal of Contemporary Hospitality Management, 22(5), 693717. doi: 10.1108/09596111011053819

Gyensare, M. A., \& Asare, J.-A. (2012). Relationship between human resource (HR) practices and perceived performance of psychiatry nurses in Ghana. African Journal of Business Management, 6(6), 2137-2142.

Hair, J. F., Ringle, C. M., \& Sarstedt, M. (2011). PLS-SEM: Indeed a silver bullet. Journal of Marketing theory Practice, 19(2), 139-152.

Hair, J. F., Ringle, C. M., \& Sarstedt, M. (2013). Partial least squares structural equation modeling: Rigorous applications, better results and higher acceptance. Long range planning, 46(1-2), 1-12.

Hartline, M. D., \& Ferrell, O. C. (1996). The management of customer-contact service employees: An empirical investigation. Journal of marketing, 60(4), 52-70.

Hayes, A. F., \& Preacher, K. J. (2014). Statistical mediation analysis with a multicategorical independent variable. British journal of mathematical statistical psychology, 67(3), 451-470.

Henseler, J., Ringle, C. M., \& Sarstedt, M. (2015). A new criterion for assessing discriminant validity in variance-based structural equation modeling. Journal of the academy of marketing science, 43(1), $115-135$.

Hewitt, A. (2009). Managing performance with incentive pay. Journal of personnel Management, 7(1), 2031.

Hulland, J. (1999). Use of partial least squares (PLS) in strategic management research: A review of four recent studies. Strategic management journal, 20(2), 195-204. 
Huselid, M. A. (1995). The impact of human resource management practices on turnover, productivity, and corporate financial performance. Academy of Management journal, 38(3), 635-672.

Hyun, S., \& Oh, H. (2011). Reexamination of Herzberg's Two-Factor Theory of Motivation in the Korean Army Foodservice Operations. Journal of Foodservice Business Research, 14(2), 100-121. doi: 10.1080/15378020.2011.574532

Ibrahim, M. G., Abdullah, H. H., \& Kaliappen, N. (2016). Effect of job satisfaction on turnover intention: an empirical investigation on Nigerian banking industry. International Journal of Organizational \& Business Exellence, 1(2), 1-8.

Ioannidou, E., Karagiorgos, T., \& Alexandris, K. (2016). Exploring the relationship of organizational commitment, organizational citizenship behavior, psychological empowerment and job satisfaction with Leader-Member Exchange of section leaders and team leaders in summer children's camps in Greece. International Journal of Sport Management, Recreation Tourism, 22, 63-80.

James, L. R., \& Brett, J. M. (1984). Mediators, moderators, and tests for mediation. Journal of Applied psychology, 69(2), 307.

Karavardar, G. (2014). Perceived organizational support, psychological empowerment, organizational citizenship behavior, job performance and job embeddedness: A research on the fast food industry in Istanbul, Turkey. International Journal of Business and Management, 9(4), 131.

Katou, A. A. (2008). Measuring the impact of HRM on organizational performance. Journal of Industrial Engineering and Management, 1(2), 119-142.

Katou, A. A., \& Budhwar, P. S. (2006). Human resource management systems and organizational performance: a test of a mediating model in the Greek manufacturing context. The International Journal of Human Resource Management, 17(7), 1223-1253.

Mehrjouyan, N. (2019). Investigating the relationship between knowledge management and job involvement on organizational agility of Khuzestan province youth and sports department staff using the structural equation model. International Journal of Education Management Studies, 9(4), 224-226.

Meier, K. J., \& O'Toole, L. J. (2012). Subjective organizational performance and measurement error: Common source bias and spurious relationships. Journal of Public Administration Research and Theory, 23(2), 429-456.

Mellahi, K. (2007). The effect of regulations on HRM: private sector firms in Saudi Arabia. The International Journal of Human Resource Management, 18(1), 85-99. doi: $10.1080 / 09585190601068359$

Mellahi, K., \& Wood, G. (2002). Desperately seeking stability: the making and remaking of the Saudi Arabian petroleum growth regime. Competition and Change, 6(4), 345-362.

Modway, R. T., Porter, L. W., Steers, R. M., \& Porter, L. W. (1982). Employee-organization linkages: The psychology of commitment, absenteeism and turnover: New York: Academic Press.

Muhammad, I. G., \& Abdullah, H. H. (2016). Assessment of organizational performance: Linking the motivational antecedents of empowerment, compensation and organizational commitment. International Review of Management Marketing, 6(4).

Ndregjoni, Z., \& Elmazi, L. (2012). The effects of relationship between information technology and firm innovation on firm performance: the case of albania. International Journal of Management Cases, 14(1), 235-246. doi: 10.5848/APBJ.2012.00023

Nitzl, C., \& Hirsch, B. (2016). The drivers of a superior's trust formation in his subordinate. Journal of Accounting Organizational Change.

Nunnally, J. C. (1978). Psychometric Theory: New York, McGraw-Hill Education.

Ostroff, C., \& Bowen, D. E. (2016). Reflections on the 2014 decade award: Is there strength in the construct of HR system strength? Academy of Management Review, 41(2), 196-214.

Parker, O., \& Wright, L. (2001). PAY AND EMPLOYEE COMMITMENT: THE MISSING LINK-The company that enhances compensation conditions and practices will likely see an improvement in employee commitment. Ivey Business Journal, 65(3), 70-73. 
Parker, R. A. (2008). Human resource handbook: a guide to effective employee management: Russell R. Mueller Retail Hardware Research Foundation.

Ramirez-Garcia, C., Perea, J. G.-Á. d., \& Junco, J. G.-D. (2019). La felicidad en el trabajo: Validación de una escala de medida. Revista de Administração de Empresas, 59(5), 327-340. doi: 10.1590/s0034759020190503

Richard, P. J., Devinney, T. M., Yip, G. S., \& Johnson, G. (2009). Measuring organizational performance: Towards methodological best practice. Journal of management, 35(3), 718-804.

Ruiz-Palomo, D., León-Gómez, A., \& García-Lopera, F. (2020). Disentangling organizational commitment in hospitality industry: The roles of empowerment, enrichment, satisfaction and gender. International Journal of Hospitality Management, 90, 102637. doi: https://doi.org/10.1016/j.ijhm.2020.102637

Shin, Y., Sung, S. Y., Choi, J. N., \& Kim, M. S. (2015). Top Management Ethical Leadership and Firm Performance: Mediating Role of Ethical and Procedural Justice Climate. Journal of Business Ethics, 129(1), 43-57. doi: 10.1007/s10551-014-2144-5

Sobaih, A. E. E., \& Hasanein, A. M. (2020). Herzberg's theory of motivation and job satisfaction: Does it work for hotel industry in developing countries? Journal of Human Resources in Hospitality \& Tourism, 19(3), 319-343. doi: 10.1080/15332845.2020.1737768

Som, A. (2008). Innovative human resource management and corporate performance in the context of economic liberalization in India. The International Journal of Human Resource Management, 19(7), 1278-1297. doi: 10.1080/09585190802110075

Taormina, R. J. (1999). Predicting employee commitment and satisfaction: The relative effects of socialization and demographics. International Journal of Human Resource Management, 10(6), 1060-1076.

Teclemichael Tessema, M., \& Soeters, J. L. (2006). Challenges and prospects of HRM in developing countries: testing the HRM-performance link in the Eritrean civil service. The International Journal of Human Resource Management, 17(1), 86-105. doi: 10.1080/09585190500366532

Teems, M., \& Helbing, E. (2017). An Investigation of job satisfaction among nurses in the emergency department.

Tholath, D. I., \& Thattil, G. S. J. I. J. o. K. M. (2016). Motivational Drivers of Knowledge Sharing in the Banking Sector of India. 14(1).

Thomas, K. W., \& Velthouse, B. A. (1990). Cognitive Elements of Empowerment: An "Interpretive" Model of Intrinsic Task Motivation. Academy of Management Review, 15(4), 666-681. doi: 10.5465/amr.1990.4310926

Uraon, R. S. (2018). Examining the impact of HRD practices on organizational commitment and intention to stay within selected software companies in India. Advances in Developing Human Resources, 20(1), 11-43.

Wan, D., Ong, C. H., \& Kok, V. (2002). Strategic Human Resource Management and Organizational Performance in Singapore. Compensation \& Benefits Review, 34(4), 33-42. doi: $10.1177 / 0886368702034004006$

Wang, Y., Liu, J., \& Zhu, Y. (2018). How does humble leadership promote follower creativity? The roles of psychological capital and growth need strength. Leadership \& Organization Development Journal, 39(4), 507-521. doi: 10.1108/LODJ-03-2017-0069

Wright, P. M., Gardner, T. M., \& Moynihan, L. M. (2003). The impact of HR practices on the performance of business units. Human Resource Management Journal, 13(3), 21-36.

Zhou, X., Vohs, K. D., \& Baumeister, R. F. (2009). The Symbolic Power of Money: Reminders of Money Alter Social Distress and Physical Pain. Psychological Science, 20(6), 700-706. doi: 10.1111/j.1467-9280.2009.02353.x

Zimmerman, M. A. (2000). Empowerment theory Handbook of community psychology (pp. 43-63): Springer. 